\title{
The Effect of Alendronate on Proteome of Hepatocellular Carcinoma Cell Lines
}

\author{
Amber Ilyas, ${ }^{1}$ Zehra Hashim, ${ }^{1}$ Nadia Naeem, ${ }^{2}$ Kanwal Haneef, ${ }^{1}$ and Shamshad Zarina ${ }^{1}$ \\ ${ }^{1}$ National Center for Proteomics, University of Karachi, Karachi 75270, Pakistan \\ ${ }^{2}$ Dr. Panjwani Center for Molecular Medicine and Drug Research, ICCBS, University of Karachi, Karachi 75270, Pakistan \\ Correspondence should be addressed to Shamshad Zarina; szarina@uok.edu.pk
}

Received 8 October 2013; Revised 13 December 2013; Accepted 14 December 2013; Published 6 February 2014

Academic Editor: Jen-Fu Chiu

Copyright (c) 2014 Amber Ilyas et al. This is an open access article distributed under the Creative Commons Attribution License, which permits unrestricted use, distribution, and reproduction in any medium, provided the original work is properly cited.

\begin{abstract}
Cancer is a life threatening disorder effecting 11 million people worldwide annually. Among various types of cancers, Hepatocellular carcinoma (HCC) has a higher rate of mortality and is the fifth leading cause of cancer related deaths around the world. Many chemotherapeutic drugs have been used for the treatment of HCC with many side effects. These drugs are inhibitors of different cell regulatory pathways. Mevalonate (MVA) pathway is an important cellular cascade vital for cell growth. A variety of inhibitors of MVA pathway have been reported for their anticancerous activity. Bisphosphonates (BPs) are members of a family involved in the treatment of skeletal complications. In recent years, their anticancer potential has been highlighted. Current study focuses on exploring the effects of alendronate (ALN), a nitrogen containing BP, on hepatocellular carcinoma cell line using genomic and proteomics approach. Our results identified ten differentially expressed proteins, of which five were up regulated and five were down regulated in ALN treated cells. Furthermore, we also performed gene expression analysis in treated and control cell lines. The study may help in understanding the molecular mechanism involved in antitumor activity of ALN, identification of possible novel drug targets, and designing new therapeutic strategies for HCC.
\end{abstract}

\section{Introduction}

Hepatocellular carcinoma is the most common form of cancer worldwide and is third most frequent cause of cancer related death [1]. In 2008, approximately 696,000 deaths were reported all over the world from HCC. The incidence of HCC is high in Eastern and South-Eastern Asia [2]. It is also the most common cause of death among cirrhosis patients [3].

Various risk factors are involved in disease onset such as tobacco, aflatoxin B1, vinyl chloride, alcohol abuse, diabetes, obesity, nonalcoholic fatty liver disease, and hemochromatosis. Hepatitis B and C infection are the most common risk factors of HCC development [4]. The prognosis of HCC is poor as compared to high incidence of recurrence due to the late detection of the disease.

Treatment strategies for early stage HCC are well established including percutaneous ethanol injection, (PEIT) [5], microwave coagulation therapy (MC) [6], transcatheter arterial embolization [7], radiofrequency ablation (RFA) [8], and hepatic resection [5]. At advanced stages, however, all these treatment modalities fail and the only option left is of palliative chemotherapy. Palliative therapy does not completely cure the disease but can only improve the survival rate and the quality of life. Since existing chemotherapeutic drugs have many side effects, identification of an effective drug remains a hot research area.

Mevalonate pathway is an important target for anticancer drugs as it governs cell cycles including cell growth and survival. Manipulation of this pathway results in alteration of cancerous cell growth [9]. Mevalonate (MVA) is synthesized from the 3-hydroxy-3-methylglutaryl coenzyme A (HMGCo A) [10]. Isoprenoids farnesyl pyrophosphate (FPP) and geranylgeranyl pyrophosphate (GPP), the end products of this pathway, play fundamental role in activation of intracellular Ras and Ras related GTP binding proteins which are critical for cell signaling cascade [11]. Approximately in $20 \%$ of all human tumors, inactivation of GTP hydrolysis occurs due to mutated Ras protein $[12,13]$ resulting in permanent activation of cell cycle, uncontrolled growth, and cell proliferation [14]. 
Bisphosphonates (BPs) are pyrophosphate analogues and are inhibitors of mevalonate (MVA) pathway, mainly Farnesyl pyrophosphate synthase (FDPS), thus preventing prenylation of small signaling proteins (Ras, Rho, and Rab) [15, 16]. BPs are potential inhibitors of bone resorption [17] and during myeloma and metastatic phase of breast and prostate cancer, BPs are used to cure the skeletal complications [18]. Nitrogen containing bisphosphonates (N-BPs) have been used for the treatment of osteoporosis and tumor related hypercalcemia [19]. There has been increasing evidence that BPs can inhibit proliferation and induce apoptosis in a variety of human tumor cells like myeloma, breast, pancreas, and prostate under various conditions [20-22]. In vitro studies have indicated that BPs can cause induction of apoptosis in human myeloma cell lines [23]. Alendronate (ALN), a BPs family member, has shown to inhibit invasion of prostate cancer [24], proliferation/invasion in human epidermal carcinoma cells [25] and to stimulate inhibitors of DNA binding/differentiation genes in $\mathrm{C} 2 \mathrm{C} 12$ cells [26]. These studies mainly refer to cell cycle arrest and apoptotic pathway induction and very few studies have been conducted at proteomics level.

Till date, no work has been reported on proteomic profiling on effects of ALN in HCC cell lines. The objective of the current study was to evaluate the effects of ALN on HCC cell lines and examine altered gene and protein expression in response to drug treatment. We have performed proteome profiling of hepatocellular carcinoma Huh-7 cells treated with ALN and control. Furthermore, we have observed the gene expression pattern of farnesyl pyrophosphate synthase (FDPS), farnesyl-diphosphate farnesyl transferase 1 (FDFT1), caspase 7 (CASP7), Rho family GTPase (RND3), Ras oncogene family member $(R A B 11 A)$, and DNA methyl transferase 1 (DNMT1) in ALN treated and control Huh-7 cells.

\section{Materials and Method}

2.1. Cell Culture and Treatment. Human hepatocellular carcinoma cell line Huh-7 were grown in Dulbecco's Modified Eagle's Medium (DMEM) with $4.5 \mathrm{~g} / \mathrm{L}$ glucose, supplemented with $10 \%$ fetal bovine serum (FBS), $2 \mathrm{mM}$ glutamine, 100 $\mathrm{U} / \mathrm{mL}$ penicillin and $100 \mu \mathrm{g} / \mathrm{mL}$ streptomycin. Cells were maintained in humidified atmosphere of $5 \% \mathrm{CO}_{2}$ at $37^{\circ} \mathrm{C}$ and routinely sub cultured using $0.05 \%$ trypsin-EDTA. The medium were changed after every two days. Exponentially growing cells were incubated with different concentrations of $\operatorname{ALN}(5,10$, and $20 \mu \mathrm{M})$ for 24,48 , and $72 \mathrm{hrs}$.

2.2. Cytotoxicity Assay. Approximately $1.2 \times 10^{6}$ cells $/ \mathrm{mL}$ $(1000 \mu \mathrm{L} /$ well) were seeded in 6 -well plates (Corning). Cells were incubated for $24 \mathrm{hrs}$ at $37^{\circ} \mathrm{C}$ in $5 \% \mathrm{CO}_{2}$ to allow cell attachment before performing cytotoxicity assay. After 24 hrs incubation, fresh medium containing different concentrations of the ALN $(5 \mu \mathrm{M}, 10 \mu \mathrm{M}$, and $20 \mu \mathrm{M})$ were added to the wells and incubated for 24, 48, and $72 \mathrm{hrs}$. After each respective time interval, media were taken and cytotoxicity assay was performed using CytoTox 96 Nonradioactive Cytotoxicity Assay(Promega) according to manu- facturer's instructions. Absorbance was taken at $490 \mathrm{~nm}$ using microplate reader (Backmann Coulter). Cell cytotoxicity was expressed as percentage against the control wells. All assays were performed in triplicate.

2.3. Analysis of Cell Cycle Using Flow Cytometry. Cells were cultured with $5 \mu \mathrm{M}$ ALN for 24,48 , and $72 \mathrm{hrs}$. After respective time interval, cells were harvested by trypsinization and washed twice with PBS. Cells were fixed in ice cold $70 \%$ ethanol, washed, and resuspended in $1 \mathrm{~mL}$ PBS. Cells were treated with $10 \mu \mathrm{L}$ (100 units/mL) RNase for 30 mins in water bath $\left(37^{\circ} \mathrm{C}\right)$ and stained with $150 \mu \mathrm{L}(20 \mu \mathrm{g} / \mathrm{mL})$ propidium iodide (PI) for $30 \mathrm{mins}$ at room temperature. Stained cells were then analyzed by flow cytometer (FACSCalibur, Becton Dickinson, USA) and DNA content was quantified by using Flow Jo software. Samples were analyzed in duplicate.

2.4. Reverse Transcriptase-PCR. Total RNA was extracted from treated and untreated (control) cells using SV Total RNA extraction kit (Promega) according to manufacturer's protocol. Purity of the extracted RNA was measured by 260/280 ratio. $\sim 4 \mu \mathrm{g}$ RNA was reverse transcribed using superscript RT kit (Invitrogen). PCR was performed to amplify the transcript of the Human FDPS, FDFT1, CASP7, $R A B 11 A, R N D 3$, and DNMT1 genes using oligonucleotide primers. Human $\beta$-Actin gene was used as an internal standard. PCR conditions were: denaturation at $94^{\circ} \mathrm{C}$ for $1 \mathrm{~min}$, annealing at $60-62^{\circ} \mathrm{C}$ for $1 \mathrm{~min}$, and extension at $74^{\circ} \mathrm{C}$ for $1 \mathrm{~min}$. Total number of amplification cycles were 30 . The primer sequences, expected product size, and annealing temperatures are listed in Table 1. PCR products were electrophoretically resolved on $2 \%$ agarose gel. Untreated Huh-7 cells and PCR blank were used as positive and negative control, respectively. Densitometry was performed to compare band densities using Quantity One Software (BioRad). The integrated density of each gene was normalized with the corresponding $\beta$-Actin band density.

2.5. 2-DE Analysis. For the extraction of protein, $5 \mu \mathrm{M}$ ALN treated and untreated (control) cells were lysed in lysis buffer containing $8 \mathrm{M}$ urea, 0.2 M EDTA, 0.5 M DTT, glycerol, NP40 , ampholyte solution $\mathrm{pH} 3-10$ in $0.5 \mathrm{M}$ Tris- $\mathrm{HCl}$ with protease inhibitor cocktail. The lysate was centrifuged at $12,000 \times \mathrm{g}$ for $10 \mathrm{mins}$ at $4^{\circ} \mathrm{C}$. Protein concentrations were measured using Bradford protein estimation kit (BioRad). Approximately $80 \mu \mathrm{g}$ protein from the treated and untreated samples were dissolved in rehydration buffer containing $8 \mathrm{M}$ Urea, 0.5\% ampholyte solution, 0.2\% DTT, 0.5\% CHAPS, and few crystals of Bromophenol blue and used to rehydrate the IPG strip 3-10 NL over night at room temperature. IEF was performed on Multiphor II (GE Healthcare) system at $20^{\circ} \mathrm{C}$ using total of $7000 \mathrm{~V} / \mathrm{h}$. IPG Strips were equilibrated for 30 mins each using equilibration buffer 1 containing $0.5 \mathrm{M}$ Tris- $\mathrm{HCl}$ (pH 6.8), $6 \mathrm{M}$ urea, $2 \%$ SDS, 30\% glycerol, and $2 \%$ DTT, then in equilibration buffer 2 consisting of $0.5 \mathrm{M}$ Tris$\mathrm{HCl}$ (pH 6.8), $6 \mathrm{M}$ urea, 2\% SDS, 30\% glycerol, and 2.5\% w/v iodoacetamide. After equilibration, strips were applied on 
TABLE 1: Forward and reverse primer sequences, product size, and annealing temperatures used in the study.

\begin{tabular}{|c|c|c|c|c|}
\hline S. no. & Gene & Primer sequence & $\mathrm{Tm}$ & Product Size \\
\hline \multirow{2}{*}{1} & \multirow{2}{*}{$\beta$-Actin } & F: 5'GGACTTCGAGCAAGAGATGG & \multirow{2}{*}{$62.4^{\circ} \mathrm{C}$} & \multirow{2}{*}{$234 \mathrm{bp}$} \\
\hline & & R: 3'AGCACTGTGTTGGCGTACAG & & \\
\hline \multirow{2}{*}{2} & \multirow{2}{*}{ FDPS } & F: 5' AGGGCAATGTGGATCTTGTC & \multirow{2}{*}{$60.4^{\circ} \mathrm{C}$} & \multirow{2}{*}{$180 \mathrm{bp}$} \\
\hline & & R: $3^{\prime}$ GAAAGAACTCССССАТСТCС & & \\
\hline \multirow{2}{*}{3} & \multirow{2}{*}{ FDFT1 } & F: 5'GGTCCCGCTGTTACACAACT & \multirow{2}{*}{$60.4^{\circ} \mathrm{C}$} & \multirow{2}{*}{$194 \mathrm{bp}$} \\
\hline & & R: $3^{\prime}$ AAAACTCTGCCATCCCAATG & & \\
\hline \multirow{2}{*}{4} & \multirow{2}{*}{ CASP7 } & F: 5'AGTGACAGGTATGGGCGTTC & \multirow{2}{*}{$61.4^{\circ} \mathrm{C}$} & \multirow{2}{*}{$164 \mathrm{bp}$} \\
\hline & & R: $3^{\prime}$ CGGCATTTGTATGGTCCTCT & & \\
\hline \multirow{2}{*}{5} & \multirow{2}{*}{ DNMT1 } & F: 5'GTGGGGGACTGTGTCTCTGT & \multirow{2}{*}{$62.4^{\circ} \mathrm{C}$} & \multirow{2}{*}{$204 \mathrm{bp}$} \\
\hline & & R: 3'TGAAAGCTGCATGTCCTCAC & & \\
\hline \multirow{2}{*}{6} & \multirow{2}{*}{$R A B 11 A$} & F: 5'CCACCACGACTGGCTAATTT & \multirow{2}{*}{$60^{\circ} \mathrm{C}$} & \multirow{2}{*}{208 bp } \\
\hline & & R: $3^{\prime}$ ATCAAGGCACCATGGCTAAC & & \\
\hline \multirow{2}{*}{7} & \multirow{2}{*}{ RND3 } & F: 5'GTGCTTGCATTTTTGGGTTT & \multirow{2}{*}{$60^{\circ} \mathrm{C}$} & \multirow{2}{*}{$226 \mathrm{bp}$} \\
\hline & & R:3' ATCCCATGGGTCCTGATACA & & \\
\hline
\end{tabular}

$12 \%$ polyacrylamide gel to run second dimension SDSPAGE at a constant voltage of 65 volts using mini protean electrophoresis system (BioRad). Gels were stained overnight using coomassie brilliant blue G-250.

2.6. Image Analysis. Gel images were acquired using ExQuest spot cutter and analyzed by PDQuest software (BioRad). For the differential protein expression analysis, a master gel image was prepared from control cells showing highest number of spots with best resolution. Spots from $5 \mu \mathrm{M}$ ALN treated gel were matched to the master gel and spot density was determined.

2.7. Protein Identification Using LC-MS/MS. To identify expressed proteins, gel spots were excised and digested with trypsin. Tryptic peptides were subjected to nLC-MS/MS analysis using Thermo LTQ XL linear ion trap MS interfaced with nano LC system. $1 \mu \mathrm{L}$ sample was injected through an autosampler into the nLC system at the flow rate of $300 \mathrm{~nL} / \mathrm{min}$. The peptides were eluted onto a $75 \mu \mathrm{m}$ I.D $\times 15 \mathrm{~cm}$ Pep-Map $100 \mathrm{C}-18$ nanocolumn. The column was equilibrated with $96.8 \% \mathrm{~A}(0.1 \%$ F.A) and $3.2 \% \mathrm{~B}(98 \% \mathrm{ACN}$, $2 \%$ water, $0.1 \%$ F.A). Peptide separation was achieved with multi-step gradient from $3.2 \%$ to $80 \%$ solution B over 70 mins. Silica tip $10+/-1 \mu \mathrm{m}$ emitter was used to apply the peptides on to LTQ MS through nanoelectrospray (NSI). The capillary voltage was set at $29.95 \mathrm{~V}$ and the capillary temperature was maintained at $270^{\circ} \mathrm{C}$. Xcalibur software version 2.0.7SP1 was used to produce RAW files and Proteome Discoverer 1.2 to convert RAW files into MGF files (see Supplementary Material available online at http://dx.doi.org/10.1155/2014/532953). Protein identification was performed using Mascot search engine against latest version of Swiss-PROT. For Mascot search, following parameters were used: peptide mass tolerance $\pm 1.5 \mathrm{Da}$, MS/MS tolerance $\pm 0.5 \mathrm{Da}$, carbamidomethylation of Cys, and Met Oxidation as fixed and variable modifications, respectively.
2.8. Statistical Analysis. Statistical analyses were performed by SPSS 20 software. The paired $t$-test was used to compare the changes in gene expression and FACS results. Statistical analysis was done to evaluate the significant differences for cells proliferation, gene expression and FACS in ALN treated and untreated cells. The differences was statistically significant if $P<0.05$.

\section{Results}

3.1. Effect of Alendronate on the Growth of Hepatocellular Carcinoma Cells In Vitro. ALN inhibited the proliferation of HCC cell lines in dose and time dependent manner (Figure 1). The effect of ALN was studied at concentration ranging from $5 \mu \mathrm{M}$ to $20 \mu \mathrm{M}$ on Huh-7 cell viability. ALN induced concentration dependent reduction in cell viability (Figure 1). Cell death was found to be negligible after $24 \mathrm{hrs}$ incubation at all concentrations except $20 \mu \mathrm{M}$. After $48 \mathrm{hrs}$ incubation at $5 \mu \mathrm{M}$ ALN, $42 \%$ inhibition in cell viability was observed which reached up to $60 \%$ after $72 \mathrm{hrs}$. Same trend was observed in case of $10 \mu \mathrm{M}$ concentration where 48 and $64 \%$ cytotoxicity was observed after 48 and $72 \mathrm{hrs,}$ respectively. Maximum inhibition (94\%) was observed at 72 hrs with $20 \mu \mathrm{M}$ concentration. Our results indicated $5 \mu \mathrm{M}$ concentration to be the most effective hence it was used for further studies.

3.2. ALN Induced Cell Cycle Alterations. Cell cycle analysis on ALN treated cells was done by Fluorescence activated cell sorting (FACS). Cell proliferation was inhibited by ALN in Huh-7 cells. Cells treated with $5 \mu \mathrm{M}$ ALN for $24 \mathrm{hrs}$ showed no change in cell proliferation while $48 \mathrm{hrs}$ and $72 \mathrm{hrs}$ ALN treatment showed increase cell proliferation at G1 and decrease at G2 phase (Figure 2).

3.3. Differential Gene Expression Analysis of the Human Hepatocellular Carcinoma Huh-7 Cells. Reverse transcription of mRNA extracted from ALN treated and untreated cells 


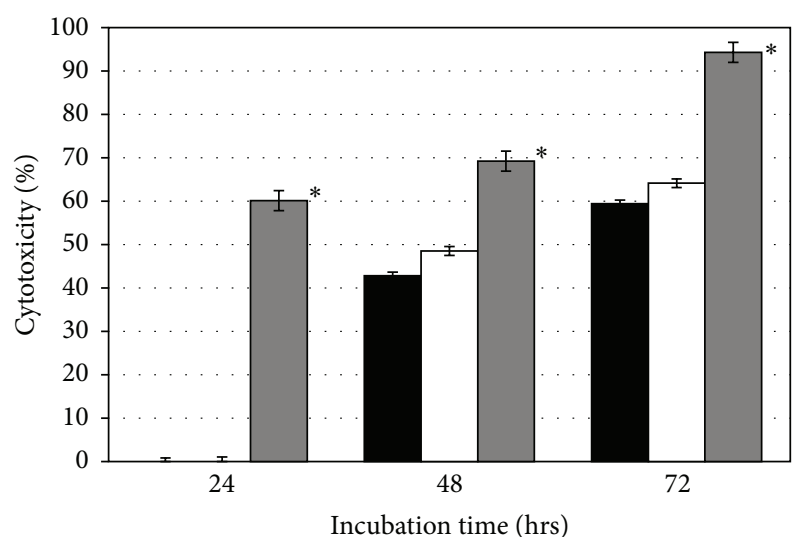

$\square \mu \mathrm{M}$ ALN
$\square 10 \mu \mathrm{M}$ ALN
$\square 20 \mu \mathrm{M}$ ALN

Figure 1: The effect of $5 \mu \mathrm{M}, 10 \mu \mathrm{M}$, and $20 \mu \mathrm{M}$ ALN on Huh-7 cells after $24 \mathrm{hrs}, 48 \mathrm{hrs}$, and $72 \mathrm{hrs}$ treatment. Cell apoptosis was determined by cytotoxicity assay. Each bar represents mean \pm S.D for $5 \mu \mathrm{M}, 10 \mu \mathrm{M}$, and $20 \mu \mathrm{M}$, respectively. ${ }^{*}$ represents statistically significant value with reference to respective control $(P<0.05)$.

showed FDPS, FDFT1, CASP7, RAB11A, RND3, and DNMT1 gene expression (Figures 3 and 4). ALN treated cells showed less expression of the FDPS gene as compared to control whereas the expression of FDFT1 and CASP7 gene was found to be increased. Expression levels of RAB11A, RND3, and $D N M T 1$ were also decreased in treated cells as compared to untreated cells. $\beta$-Actin expression was same in treated and untreated Huh-7 cells. Results are represented as mean \pm S.D while $P<0.05$ was used as statistically significant difference.

3.4. Mass Spectrometry Identification of Differentially Expressed Proteins. Figures 5(a) and 5(b) show two dimensional gel electrophoresis patterns of untreated and ALN treated HCC cell lines, respectively. Ten differentially expressed spots were identified by LC-MS/MS analysis as shown in Table 2 . Among these, 5 proteins were found to be upregulated, whereas 5 were downregulated in ALN treated HCC cell lines. The identified proteins were classified according to their biological function in order to evaluate their association with HCC and ALN treatment and were found to be mainly involved in cellular growth, signal transduction pathways, and metabolism (Figure 6).

\section{Discussion}

BPs are synthetic analogues of drugs commonly used for the treatment of osteoporosis and in cancer-induced bone diseases [19]. There has been an increasing evidence that they have anticancerous activity and can induce tumor cell death through induction of apoptosis. BPs have shown promising inhibitory effect on tumor cell proliferation/survival or on cell invasiveness in human epidermoid carcinoma, breast cancer, and small cell lung carcinoma $[25,27,28]$.

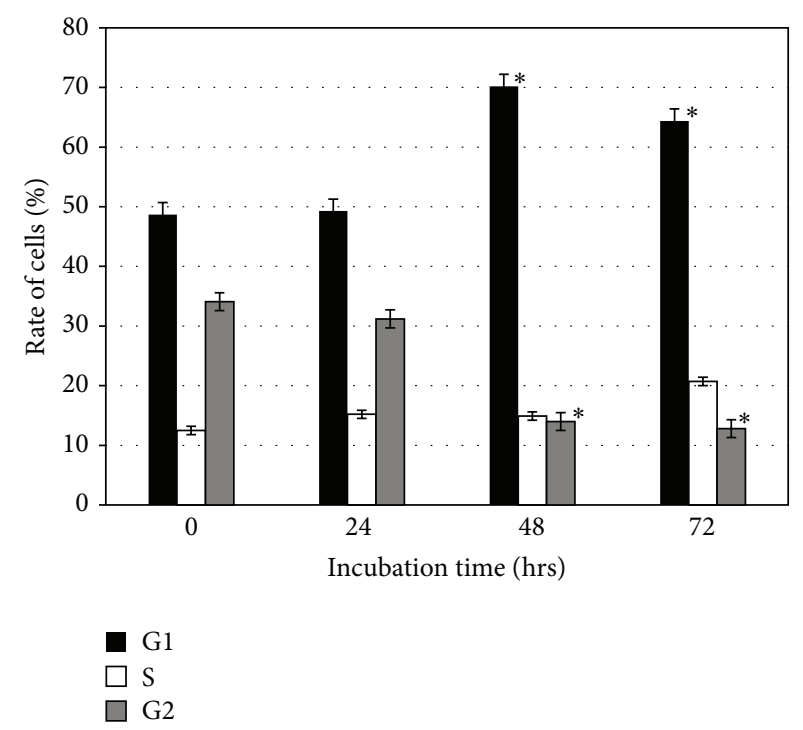

FIGURE 2: Quantification of the cell progression phases of ALN treated cells at $5 \mu \mathrm{M}$ for 24,48 , and 72 hrs by FACS. ${ }^{*}$ represents statistically significant value with reference to respective control $(P<0.05)$.

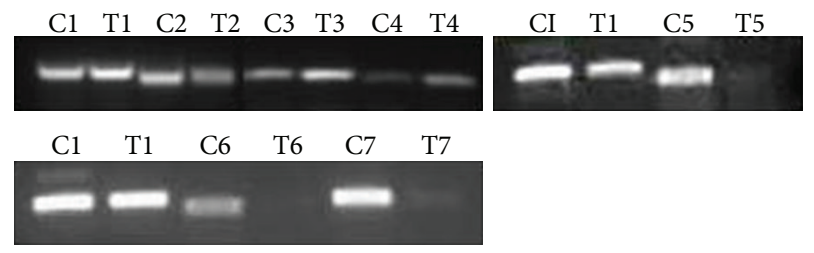

Figure 3: Expression level of $\beta$-Actin (C1, T1), FDPS (C2, T2), FDFT1 (C3, T3), CASP7 (C4, T4), DNMT1 (C5, T5), RAB11A (C6, T6), and RND3 $(\mathrm{C} 7, \mathrm{~T} 7) \mathrm{mRNA}$ in $5 \mu \mathrm{M}$ ALN treated $(\mathrm{T})$ and untreated $(\mathrm{C})$ Huh 7 cells.

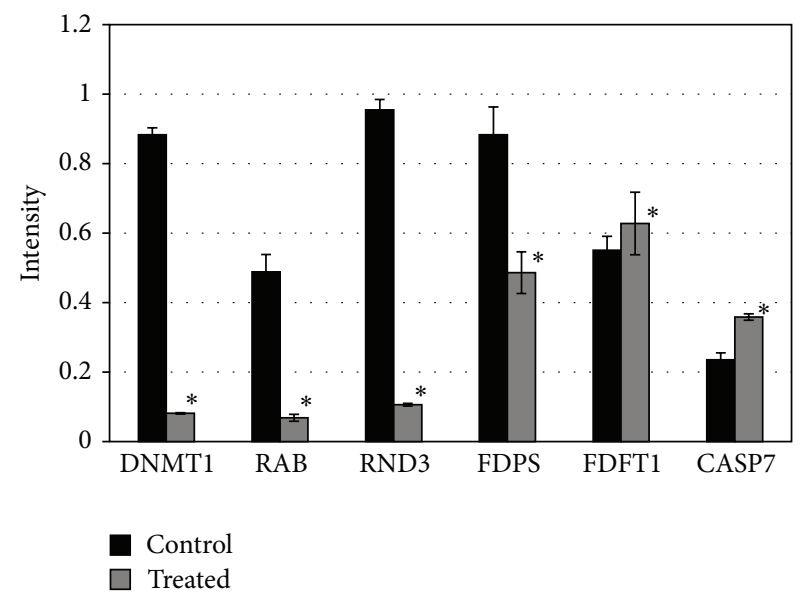

FIgURE 4: The corresponding expression abundance of DNMT1, RAB11A, RND3, FDPS, FDFT1, and CASP7 mRNA in $5 \mu \mathrm{M}$ ALN treated and control Huh 7 cells. ${ }^{*}$ represents statistically significant value $(P<0.05)$. 
TABLE 2: Differentially expressed proteins identified with nano LC-MS/MS from Huh-7 cell lines.

\begin{tabular}{|c|c|c|c|c|c|c|c|c|}
\hline Spot no. & Protein Name & Accession no. & $\begin{array}{c}\text { Sequence } \\
\text { coverage } \%\end{array}$ & $\mathrm{Mol} \cdot \mathrm{wt} \cdot \mathrm{kDa}$ & $\mathrm{pI}$ & $\begin{array}{c}\text { Protein } \\
\text { expression }\end{array}$ & $\begin{array}{l}\text { Peptide } \\
\text { matches }\end{array}$ & Function \\
\hline 1 & Heat shock protein 90 & P08238 & 6 & 90 & 4.73 & $\uparrow$ & $3(1)$ & Stress responce \\
\hline 2 & $\begin{array}{l}60 \mathrm{kDa} \text { Heat shock } \\
\text { protein }\end{array}$ & P10809 & 34 & 61 & 5.7 & $\uparrow$ & $28(17)$ & Protein folding \\
\hline 3 & $\begin{array}{l}\text { Protein dicaudal D } \\
\text { homolog } 1 \text { isoform } 1\end{array}$ & Q96G01 & 6 & 111 & 5.6 & $\downarrow$ & $9(3)$ & Interacts with RAB6A \\
\hline 4 & $\begin{array}{l}\text { Signal transducer and } \\
\text { activator of transcription } \\
\text { 1-alpha/beta }\end{array}$ & P42224 & 4 & 87 & 5.7 & $\downarrow$ & $3(1)$ & Signal transduction \\
\hline 5 & $\begin{array}{l}\text { Ras-specific guanine } \\
\text { nucleotide-releasing } \\
\text { factor }\end{array}$ & Q86X27 & 3 & 65 & 8.86 & $\downarrow$ & $3(2)$ & Signal transduction \\
\hline 6 & Annexin A5 & P08758 & 24 & 36 & 4.9 & $\uparrow$ & $8(6)$ & $\begin{array}{l}\text { Blood coagulation, } \\
\text { haemostasis, signal } \\
\text { transduction }\end{array}$ \\
\hline 7 & $\begin{array}{l}\text { Triosephosphate } \\
\text { isomerase }\end{array}$ & P60174 & 13 & 26.8 & 7.10 & $\uparrow$ & $2(2)$ & Metabolism \\
\hline 8 & Interleukin-7 & P13232 & 8 & 20 & 8.87 & $\downarrow$ & $5(1)$ & \multirow{3}{*}{$\begin{array}{l}\text { Growth factor activity } \\
\text { Antiapoptosis, } \\
\text { detoxification } \\
\text { Antiapoptosis, signal } \\
\text { transduction }\end{array}$} \\
\hline 9 & $\begin{array}{l}\text { Glutathione } \\
\text { S-transferase P }\end{array}$ & P09211 & 49 & 235 & 5.4 & $\downarrow$ & $13(11)$ & \\
\hline 10 & Peroxiredoxin-2 & P32119 & 29 & 22 & 5.66 & $\uparrow$ & $5(5)$ & \\
\hline
\end{tabular}

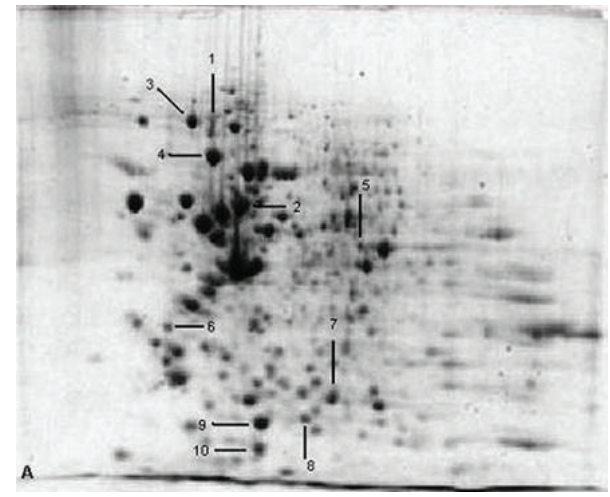

(a)

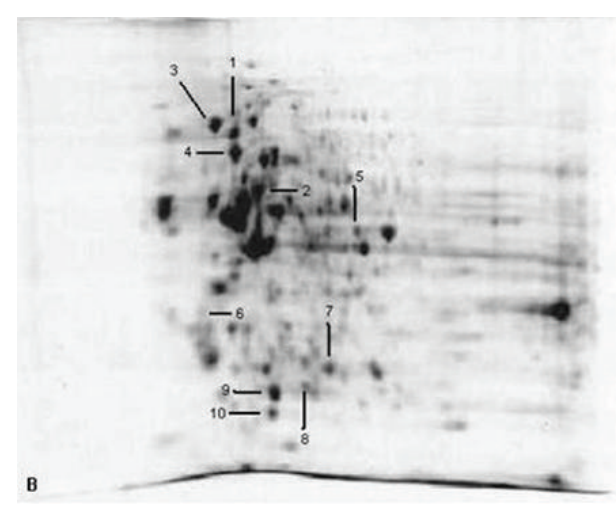

(b)

FIGURE 5: Differential proteomic analysis of $5 \mu \mathrm{M}$ ALN treated (b) and untreated control (a) Huh-7 cells using 2D gels. Differentially expressed spots identified by MS/MS analysis are marked with arrows.

Earlier incubation studies on cancer cell lines indicated that N-BPs are effective in high concentrations [29]. NBPs such as pamidronate, zoledronate, or ibandronate were used in $100 \mu \mathrm{mol} / \mathrm{L}$ concentrations to induce apoptosis in breast and prostate cancer cells. ALN, on the other hand, has shown to inhibit invasion of prostate cancer in vitro at low concentration [24]. It also prevents migration of the cells without affecting the apoptosis in vitro [30]. These reports have suggested that ALN might be effective in low and moderate concentrations in vivo. In present study, ALN has shown direct cytotoxic effect on hepatocellular carcinoma cell lines. We observed $5 \mu \mathrm{M}$ to be an effective concentration that induced $42 \%$ cell death after $48 \mathrm{hrs}$ incubation hence substantiating earlier reports. We also found significant antiproliferative effects of ALN on HCC. Our findings are in agreement with previous report suggesting ALN is effective in time and dose dependent manner [31].

N-BPs are potent inhibitors of MVA pathway as postulated in Figure 7 [32]. The molecular mechanism they work through involves binding of N-BPs with key regulatory enzyme, FDPS, resulting in inhibition of prenylation of small signaling proteins including Rho, Ras, and Rab. Treatment of Huh-7 cells with ALN resulted in apoptosis through inhibition of FDPS. We observed decreased mRNA expression of FDPS in ALN treated cells confirming that the mode of action of ALN is through regulating FDPS. Effect of ALN on FPP and GGPP can be rescued by the addition of FPP and GGPP that ultimately save the activity of Ras and Rho family proteins [33]. The branching point in MVA pathway involves FPP, the product of FDPS, which serves as a precursor for cholesterol 


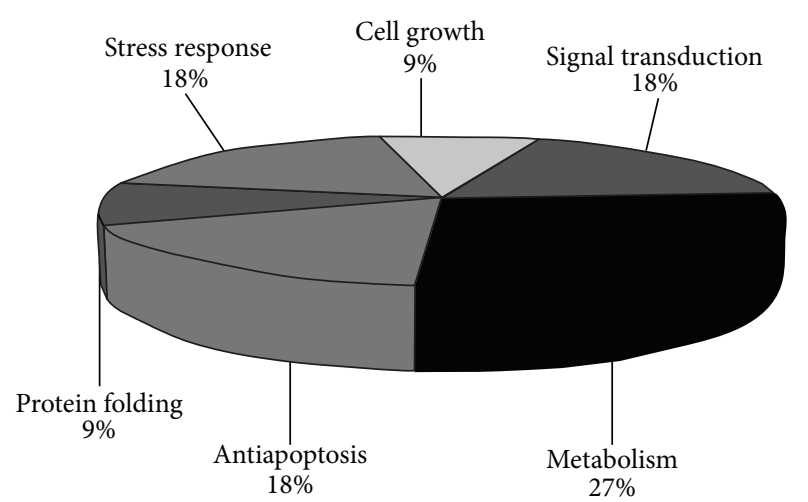

FIgURE 6: Distribution of identified proteins according to cellular function.

synthesis and protein prenylation [34]. A recent study has reported that N-BPs mediate their effect through suppression of GGPP synthetic pathway [35] while cholesterol synthesis pathway remains unaffected [36]. To examine the effect of ALN on protein prenylation, expression of RAB11A and $R N D 3$ genes (corresponding to Rho and Ras protein families resp.) was studied which was found to be decreased. We also checked expression of FDFT1 (gene encoding squalene synthase, first enzyme of cholesterol synthesis) and found it to be up regulated in ALN treated cells. Indeed, squalene synthase is not a possible target of ALN inhibition [37] and ALN is proposed to be a poor inhibitor in contrast to other $\mathrm{N}$-BPs such as incadronate and ibandronate [38]. BPs are reported to act through changes in CpG-methylation state of gene promoter regions involved in the cell proliferation and apoptosis [39]. To examine the effect of ALN on promoter methylation, we examined gene expression of DNMT1, an enzyme responsible for $\mathrm{CpG}$ methylation during cell replication [40]. In ALN treated cells, decreased expression of DNMT1 was observed suggesting BPs can modulate CpG methylation of gene promoters.

Caspases (cysteinyl aspartate-specific protease) are the key regulatory enzymes of the apoptotic cascades [41]. The gene expression of CASP7 was analyzed to investigate the molecular mechanism of apoptosis induced by ALN. Earlier studies showed that the expression of cleaved caspases 6, 7 , and 9 is increased in time and concentration dependent manner during apoptosis [42]. We also found the increased expression of CASP7 gene in ALN treated Huh 7 cells. Our results prove that in ALN treated cells, apoptotic pathway is progressed due to which increased CASP7 gene expression was observed.

To compliment gene expression study, we analyzed differential proteome profile of ALN treated and control cells. We have performed first proteomics study of hepatocellular carcinoma Huh-7 cell lines treated with ALN. We identified 5 up regulated and 5 down regulated proteins with different biological functions (Table 2). Most of the identified proteins have been reported to be involved in HCC progression, transcription, and cell growth (Figure 6).

In our study, elevated expression of peroxiredoxin $2(\operatorname{Prx}$ 2) was observed in ALN treated cells. Prx 2 is a member of

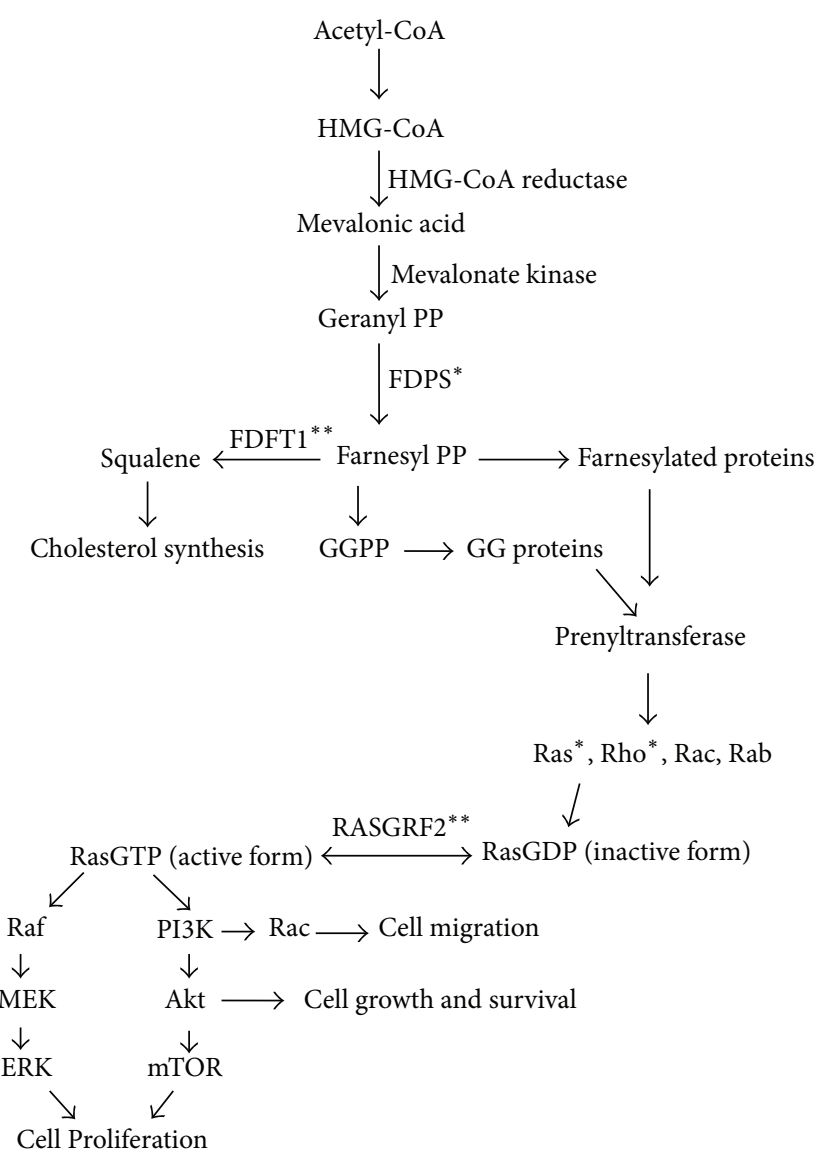

Figure 7: Flow diagram indicating mevalonate pathway. PP (pyrophosphate), FDPS (Farnesyl pyrophosphate synthase), FDFT1 (farnesyl-diphosphate farnesyltransferase 1), FPP (Farnesylpyrophosphate), GGPP (geranylgeranyl pyrophosphate), Rho, Ras, Rab, Rac (small GTPases), and RASGRF2 (Ras-specific guanine nucleotide-releasing factor). ${ }^{* *}$ and ${ }^{*}$ show up and down regulation of genes and proteins respectively as observed in current study.

peroxiredoxin protein family that provides cellular defense against oxidative stress [43]. Prx 2 is also involved in cell signaling pathways of tumor necrosis factor- $\alpha$ and growth factor by regulating intracellular levels of $\mathrm{H}_{2} \mathrm{O}_{2}[44,45]$. A recent study reported low expression of Prx 2 in human melanoma [46] which is most likely due to hyper-methylation of CpG island in promoter region [47]. In HCC tissue, Prx 2 was down regulated hence was considered as a tumor suppressor [48]. Our in vitro study revealed an up-regulation of Prx 2 in ALN treated cells substantiating its role as a possible tumor suppressor. This result is also supported by decreased expression of DNMT1 as observed in this study.

Ras protein-specific guanine nucleotide-releasing factor 2 (RASGRF2) is a Ras signaling protein [49] which regulates conversion of active/inactive forms of Ras proteins. Our results show a decreased expression of RASGRF2 in ALN treated cells. Indeed, this observation substantiates results of gene expression analysis and suggests the pathway of ALN leading to tumor cell death or apoptosis. 
We report decreased expression of IL-7 and STAT protein in ALN treated Huh-7 cells. Interleukin (IL) 7 is a cytokine that stimulates the development and proliferation of malignant cells such as in leukaemia and lymphoma [50]. IL-7 gene is expressed in many solid tumors including head and neck squamous cell carcinoma [51], renal [52], esophageal [53], and Warthin's tumour of the parotid gland [54]. IL-7 binding to its ligand triggers a series of intracellular phosphorylation events such as activation of phosphoinositide 3 kinase (PI3$\mathrm{K}$ ), Janus kinases (JAK-1 and JAK-3), signal transducers and activators of transcription (STAT) [55]. These molecules are involved in many cellular processes such as cell adhesion, cellular differentiation, motility, and mitogenesis $[56,57]$.

\section{Conclusion}

Current in vitro study presents first report on proteomics analysis of ALN treated hepatocarcinoma cell line Huh-7. Our study provides a baseline proteomics data and confirms that the mode of action of ALN is through mevalonate pathway. Furthermore, ALN in moderate concentration is sufficient to activate apoptotic pathway and may provide a strategic platform to develop novel compounds for chemotherapies of human malignancies.

\section{Conflict of Interests}

The authors declare that there is no conflict of interests regarding the publication of this paper.

\section{Acknowledgments}

Amber Ilyas is an indigenous scholar. Higher Education Commission (Islamabad) is acknowledged for provision of stipend to her. Authors acknowledge Dr. Charles Rice from The Rockefeller University, NY, for providing Huh-7 cells for this study.

\section{References}

[1] H. B. El-Serag and K. L. Rudolph, "Hepatocellular carcinoma: epidemiology and molecular carcinogenesis," Gastroenterology, vol. 132, no. 7, pp. 2557-2576, 2007.

[2] J. Ferlay, H.-R. Shin, F. Bray, D. Forman, C. Mathers, and D. M. Parkin, "Estimates of worldwide burden of cancer in 2008: GLOBOCAN 2008," International Journal of Cancer, vol. 127, no. 12, pp. 2893-2917, 2010.

[3] W. Alazawi, M. Cunningham, J. Dearden, and G. R. Foster, "Systematic review: outcome of compensated cirrhosis due to chronic hepatitis C infection," Alimentary Pharmacology and Therapeutics, vol. 32, no. 3, pp. 344-355, 2010.

[4] R. N. Aravalli, C. J. Steer, and E. N. K. Cressman, "Molecular mechanisms of hepatocellular carcinoma," Hepatology, vol. 48, no. 6, pp. 2047-2063, 2008.

[5] M. Ebara, M. Ohto, N. Sugiura et al., "Percutaneous ethanol injection for the treatment of small hepatocellular carcinoma. Study of 95 patients," Journal of Gastroenterology and Hepatology, vol. 5, no. 6, pp. 616-626, 1990.
[6] T. Seki, M. Wakabayashi, T. Nakagawa et al., "Ultrasonically guided percutaneous microwave coagulation therapy for small hepatocellular carcinoma," Cancer, vol. 74, no. 3, pp. 817-825, 1994.

[7] O. Matsui, M. Kadoya, J. Yoshikawa et al., "Small hepatocellular carcinoma: treatment with subsegmental transcatheter arterial embolization," Radiology, vol. 188, no. 1, pp. 79-83, 1993.

[8] T. Livraghi, S. N. Goldberg, S. Lazzaroni, F. Meloni, L. Solbiati, and G. S. Gazelle, "Small hepatocellular carcinoma: treatment with radio-frequency ablation versus ethanol injection," Radiology, vol. 210, no. 3, pp. 655-661, 1999.

[9] K. M. Swanson and R. J. Hohl, "Anti-cancer therapy: targeting the mevalonate pathway," Current Cancer Drug Targets, vol. 6, no. 1, pp. 15-37, 2006.

[10] J. L. Goldstein and M. S. Brown, "Regulation of the mevalonate pathway," Nature, vol. 343, no. 6257, pp. 425-430, 1990.

[11] P. M. Ghosh, G. E. Mott, N. Ghosh-Choudhury et al., "Lovastatin induces apoptosis by inhibiting mitotic and post-mitotic events in cultured mesangial cells," Biochimica et Biophysica Acta, vol. 1359, no. 1, pp. 13-24, 1997.

[12] M. Barbacid, "ras genes," Annual Review of Biochemistry, vol. 56, pp. 779-827, 1987.

[13] J. L. Bos, “The ras gene family and human carcinogenesis," Mutation Research, vol. 195, no. 3, pp. 255-271, 1988.

[14] N. M. G. M. Appels, J. H. Beijnen, and J. H. M. Schellens, "Development of farnesyl transferase inhibitors: a review," The Oncologist, vol. 10, no. 8, pp. 565-578, 2005.

[15] R. Koshimune, M. Aoe, S. Toyooka et al., "Anti-tumor effect of bisphosphonate (YM529) on non-small cell lung cancer cell lines," BMC Cancer, vol. 7, article 8, 2007.

[16] M. J. Rogers, J. C. Crockett, F. P. Coxon, and J. Mönkkönen, "Biochemical and molecular mechanisms of action of bisphosphonates," Bone, vol. 49, no. 1, pp. 34-41, 2011.

[17] H. Fleisch, "Bisphosphonates: pharmacology and use in the treatment of tumour-induced hypercalcaemic and metastatic bone disease," Drugs, vol. 42, no. 6, pp. 919-944, 1991.

[18] M. Goffinet, M. Thoulouzan, A. Pradines et al., "Zoledronic acid treatment impairs protein geranyl-geranylation for biological effects in prostatic cells," BMC Cancer, vol. 6, article 60, 2006.

[19] A. A. Reszka and G. A. Rodan, "Nitrogen-containing bisphosphonate mechanism of action," Mini-Reviews in Medicinal Chemistry, vol. 4, no. 7, pp. 711-719, 2004.

[20] R. Takahashi, C. Shimazaki, T. Inaba et al., "A newly developed bisphosphonate, YM529, is a potent apoptosis inducer of human myeloma cells," Leukemia Research, vol. 25, no. 1, pp. 77-83, 2001.

[21] S. G. Senaratne, G. Pirianov, J. L. Mansi, T. R. Arnett, and K. W. Colston, "Bisphosphonates induce apoptosis in human breast cancer cell lines," British Journal of Cancer, vol. 82, no. 8, pp. 1459-1468, 2000.

[22] M. V. Lee, E. M. Fong, F. R. Singer, and R. S. Guenette, "Bisphosphonate treatment inhibits the growth of prostate cancer cells," Cancer Research, vol. 61, no. 6, pp. 2602-2608, 2001.

[23] C. M. Shipman, M. J. Rogers, J. F. Apperley, R. G. G. Russell, and P. I. Croucher, "Bisphosphonates induce apoptosis in human myeloma cell lines: a novel anti-tumour activity," British Journal of Haematology, vol. 98, no. 3, pp. 665-672, 1997.

[24] S. S. Virtanen, H. K. Väänänen, P. L. Härkönen, and P. T. Lakkakorpi, "Alendronate inhibits invasion of PC-3 prostate 
cancer cells by affecting the mevalonate pathway," Cancer Research, vol. 62, no. 9, pp. 2708-2714, 2002.

[25] S. Muller, E. Migianu, M. Lecouvey, M. Kraemer, and O. Oudar, "Alendronate inhibits proliferation and invasion of human epidermoid carcinoma cells in vitro," Anticancer Research, vol. 25, no. 4, pp. 2655-2660, 2005.

[26] A. R. Kang, Y. R. Oh, H. Y. Kim et al., "Up-regulation of inhibitors of DNA binding/differentiation gene during alendronate-induced osteoblast differentiation," Archives of Gynecology and Obstetrics, vol. 285, no. 5, pp. 1331-1338, 2012.

[27] N. Kohno and I. Kokufu, "Prevention of bone metastases from breast cancer by adjuvant bisphosphonate therapy," Breast Cancer, vol. 10, no. 1, pp. 33-37, 2003.

[28] K. Hashimoto, K.-I. Morishige, K. Sawada et al., "Alendronate inhibits intraperitoneal dissemination in in vivo ovarian cancer model," Cancer Research, vol. 65, no. 2, pp. 540-545, 2005.

[29] T. Hiraga, P. J. Williams, G. R. Mundy, and T. Yoneda, "The bisphosphonate ibandronate promotes apoptosis in MDA-MB231 human breast cancer cells in bone metastases," Cancer Research, vol. 61, no. 11, pp. 4418-4424, 2001.

[30] K. Sawada, K.-I. Morishige, M. Tahara et al., "Alendronate inhibits lysophosphatidic acid-induced migration of human ovarian cancer cells by attenuating the activation of Rho," Cancer Research, vol. 62, no. 21, pp. 6015-6020, 2002.

[31] M. Susa, T. Morii, H. Yabe et al., "Alendronate inhibits growth of high-grade chondrosarcoma cells," Anticancer Research, vol. 29, no. 6, pp. 1879-1888, 2009.

[32] L. Gong, R. B. Altman, and T. E. Klein, "Bisphosphonates pathway," Pharmacogenetics and Genomics, vol. 21, no. 1, pp. 5053, 2011.

[33] R. Ebert, S. Zeck, R. Krug et al., "Pulse treatment with zoledronic acid causes sustained commitment of bone marrow derived mesenchymal stem cells for osteogenic differentiation," Bone, vol. 44, no. 5, pp. 858-864, 2009.

[34] I. Buhaescu and H. Izzedine, "Mevalonate pathway: a review of clinical and therapeutical implications," Clinical Biochemistry, vol. 40, no. 9-10, pp. 575-584, 2007.

[35] M. Tsubaki, T. Itoh, T. Satou et al., "Nitrogen-containing bisphosphonates induce apoptosis of hematopoietic tumor cells via inhibition of Ras signaling pathways and Bim-mediated activation of the intrinsic apoptotic pathway," Biochemical Pharmacology, vol. 85, no. 2, pp. 163-172, 2013.

[36] X. Jiang, H. Pan, J. F. Nabhan et al., "A novel EST-derived RNAi screen reveals a critical role for farnesyl diphosphate synthase in $\beta 2$-adrenergic receptor internalization and down-regulation," The FASEB Journal, vol. 26, no. 5, pp. 1995-2007, 2012.

[37] R. K. Keller and S. J. Fliesler, "Mechanism of aminobisphosphonate action: characterization of alendronate inhibition of the isoprenoid pathway," Biochemical and Biophysical Research Communications, vol. 266, no. 2, pp. 560-563, 1999.

[38] D. Amin, S. A. Cornell, S. K. Gustafson et al., "Bisphosphonates used for the treatment of bone disorders inhibit squalene synthase and cholesterol biosynthesis," Journal of Lipid Research, vol. 33, no. 11, pp. 1657-1663, 1992.

[39] R. Thaler, S. Spitzer, H. Karlic, C. Berger, K. Klaushofer, and F. Varga, "Ibandronate increases the expression of the proapoptotic gene FAS by epigenetic mechanisms in tumor cells," Biochemical Pharmacology, vol. 85, no. 2, pp. 173-185, 2013.

[40] C. Gazin, N. Wajapeyee, S. Gobeil, C.-M. Virbasius, and M. R. Green, "An elaborate pathway required for Ras-mediated epigenetic silencing," Nature, vol. 449, no. 7165, pp. 1073-1077, 2007.

[41] T.-J. Fan, L.-H. Han, R.-S. Cong, and J. Liang, "Caspase family proteases and apoptosis," Acta Biochimica et Biophysica Sinica, vol. 37, no. 11, pp. 719-727, 2005.

[42] K. Suyama, Y. Noguchi, T. Tanaka et al., "Isoprenoidindependent pathway is involved in apoptosis induced by risedronate, a bisphosphonate, in which Bim plays a critical role in breast cancer cell line MCF-7," Oncology Reports, vol. 18, no. 5, pp. 1291-1298, 2007.

[43] I. Csiki, K. Yanagisawa, N. Haruki et al., “Thioredoxin-1 modulates transcription of cyclooxygenase-2 via hypoxia-inducible factor- $1 \alpha$ in non-small cell lung cancer," Cancer Research, vol. 66, no. 1, pp. 143-150, 2006.

[44] S. W. Kang, H. Z. Chae, M. S. Seo, K. Kim, I. C. Baines, and S. G. Rhee, "Mammalian peroxiredoxin isoforms can reduce hydrogen peroxide generatedin response to growth factors and tumor necrosis factor- $\alpha$," Journal of Biological Chemistry, vol. 273, no. 11, pp. 6297-6302, 1998.

[45] C. K. Sen, "Redox signaling and the emerging therapeutic potential of thiol antioxidants," Biochemical Pharmacology, vol. 55, no. 11, pp. 1747-1758, 1998.

[46] D. J. Lee, D. H. Kang, M. Choi et al., "Peroxiredoxin-2 represses melanoma metastasis by increasing E-Cadherin/ $\beta$ Catenin complexes in adherens junctions," Cancer Research, vol. 73, no. 15, pp. 1-14, 2013.

[47] J. Furuta, Y. Nobeyama, Y. Umebayashi, F. Otsuka, K. Kikuchi, and T. Ushijima, "Silencing of Peroxiredoxin 2 and aberrant methylation of $33 \mathrm{CpG}$ islands in putative promoter regions in human malignant melanomas," Cancer Research, vol. 66, no. 12, pp. 6080-6086, 2006.

[48] J. Ai, Y. Tan, W. Ying et al., "Proteome analysis of hepatocellular carcinoma by laser capture microdissection," Proteomics, vol. 6, no. 2, pp. 538-546, 2006.

[49] I. Arozarena, D. Matallanas, M. T. Berciano et al., "Activation of H-Ras in the endoplasmic reticulum by the RasGRF family guanine nucleotide exchange factors," Molecular and Cellular Biology, vol. 24, no. 4, pp. 1516-1530, 2004.

[50] T. Takakuwa, S. Nomura, F. Matsuzuka, H. Inoue, and K. Aozasa, "Expression of interleukin-7 and its receptor in thyroid lymphoma," Laboratory Investigation, vol. 80, no. 10, pp. 14831490, 2000.

[51] V. Paleri, A. Pulimood, G. R. Davies, and M. A. Birchall, "Interleukins 7 and 12 are expressed in head and neck squamous cancer," Clinical Otolaryngology and Allied Sciences, vol. 26, no. 4, pp. 302-306, 2001.

[52] P. Trinder, "Constitutive and IFN- $\gamma$ regulated expression of IL7 and IL-15 in human renal cell cancer," International Journal of Oncology, vol. 14, no. 1, pp. 23-31, 1999.

[53] M. Oka, K. Hirose, N. Iizuka et al., "Cytokine mRNA expression patterns in human esophageal cancer cell lines," Journal of Interferon and Cytokine Research, vol. 15, no. 11, pp. 1005-1009, 1995.

[54] T. Takeuchi, H. Yamanouchi, Q. Yue, and Y. Ohtsuki, "Epithelial component of lymphoid stroma-rich Warthin's tumour expresses interleukin (IL)-7," Histopathology, vol. 32, no. 4, pp. 383-384, 1998.

[55] B. M. J. Foxwell, C. Beadling, D. Guschin, I. Kerr, and D. Cantrell, "Interleukin-7 can induce the activation of Jak 1, Jak 3 and STAT 5 proteins in murine T cells," European Journal of Immunology, vol. 25, no. 11, pp. 3041-3046, 1995. 
[56] A. Toker and L. C. Cantley, "Signalling through the lipid products of phosphoinositide-3-OH kinase," Nature, vol. 387, no. 6634, pp. 673-676, 1997.

[57] B. Vanhaesebroeck, S. J. Leevers, G. Panayotou, M. D. Waterfield, and M. D. Waterfield, "Phosphoinositide 3-kinases: a conserved family of signal transducers," Trends in Biochemical Sciences, vol. 22, no. 7, pp. 267-272, 1997. 

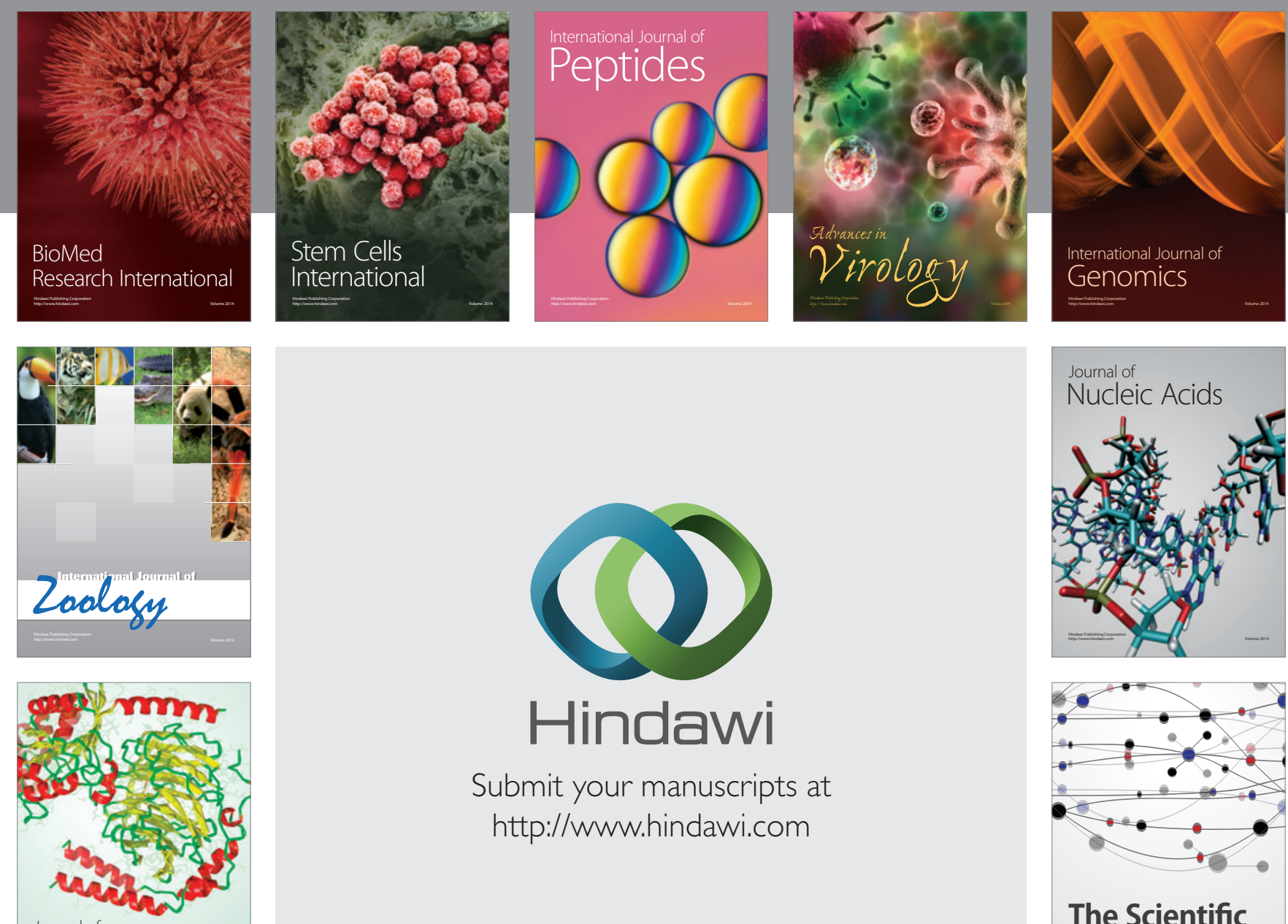

Submit your manuscripts at

http://www.hindawi.com

Journal of
Signal Transduction
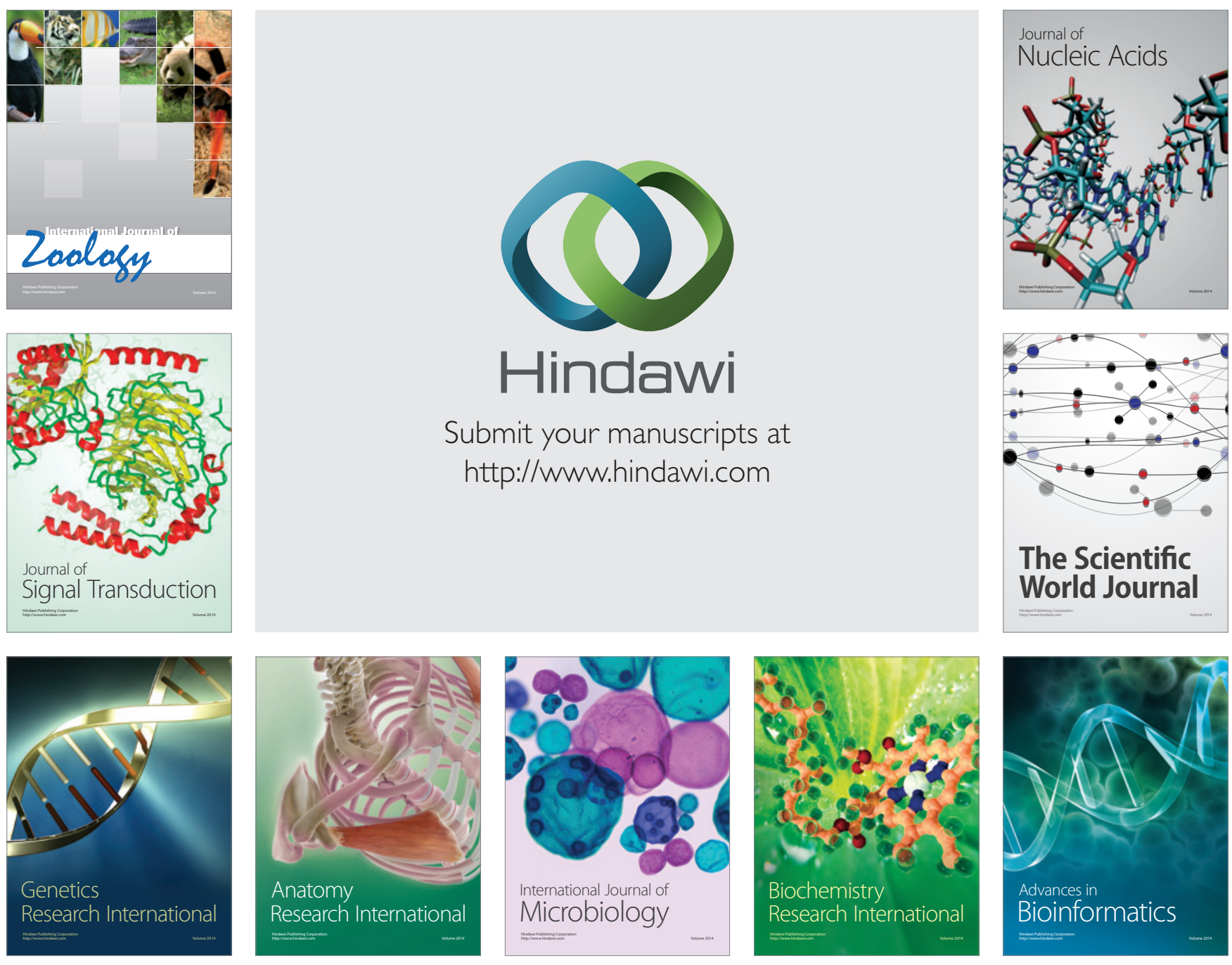

The Scientific World Journal
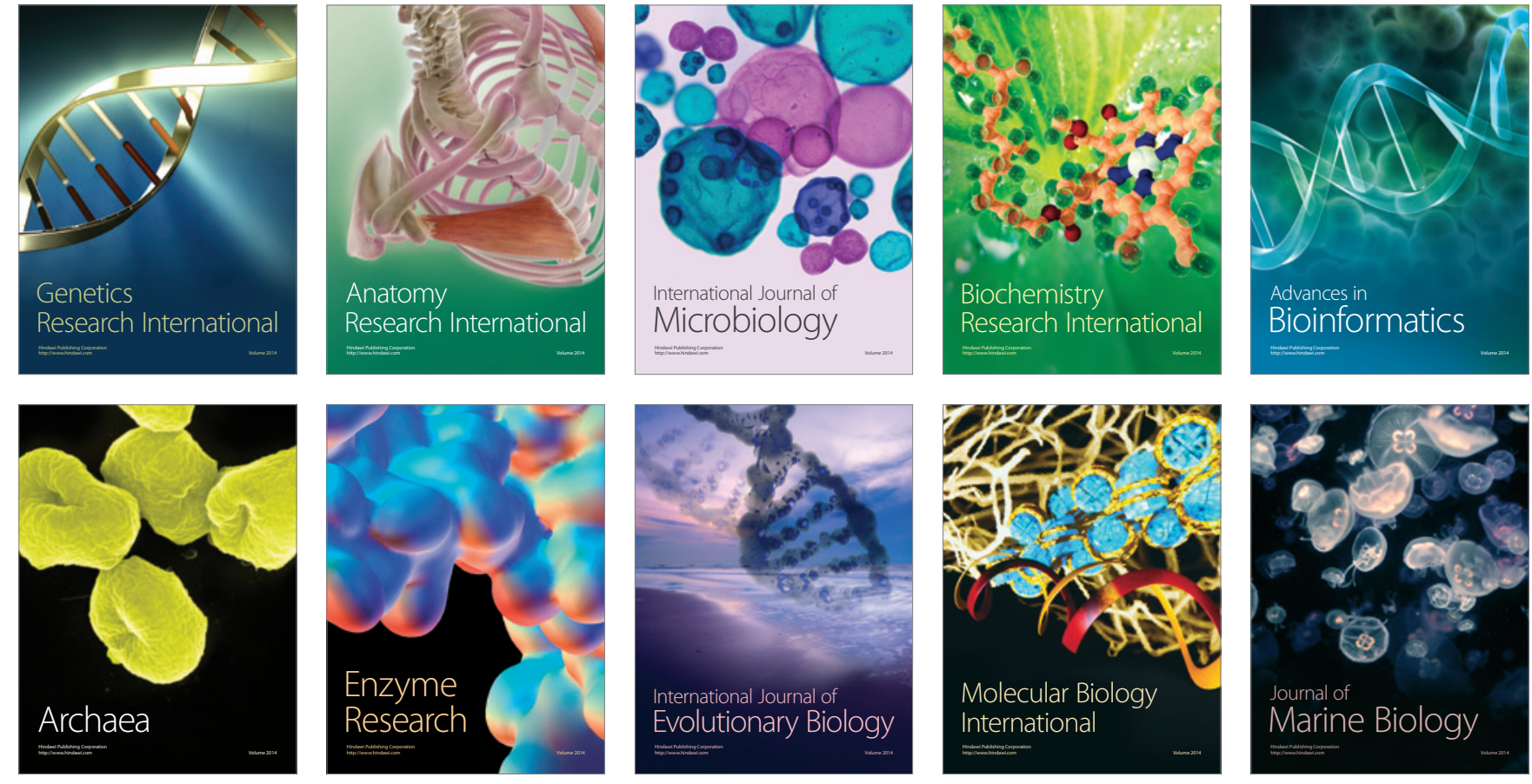